\title{
Peertechz
}

\section{Use of reconstruction plate and intramedullary pin for repair of a tibiotarsus fracture in a red-legged seriema (Cariama cristata, Linnaeus, 1766): Case}

Received: 07 April, 2021

Accepted: 30 June, 2021

Published: 01 July, 2021

*Corresponding author: Rodrigo Hidalgo Friciello Teixeira, Parque Zoológico Municipal "Quinzinho de Barros", Brazil, Tel: +5511982890169.

E-mail:rhftzoo@hotmail.com

Keywords: Orthopedy; Avian surgery; Wild birds https://www.peertechzpublications.com

Check for updates

\section{report}

\section{Michelle Colpani Fernandes ${ }^{1}$, André Luis Mota da Costa ${ }^{1}$, Thais Fernanda da Silva Machado Camargo ${ }^{2}$, Lourenço Candido Cotes ${ }^{2}$, Flávia Paiffer ${ }^{2}$, Luan de Souza Santos², Reinaldo Caetano Silva ${ }^{2}$ and Rodrigo Hidalgo Friciello Teixeira ${ }^{1,2 *}$}

Parque Zoológico Municipal “Quinzinho de Barros”, Brazil ${ }^{2}$ Universidade de Sorocaba, Brazil

\begin{abstract}
Car accidents are the main cause of death among wild birds in Brazil, especially in those with terrestrial habits, such as the red-legged seriema (Cariama cristata). These accidents keep increasing because of urbanization, making it important to present new treatments than can help decrease the number of deaths and bring welfare to the animal. In this case report, a wild red-legged seriema was found hurt nearby a driveway. Radiographs showed a multi-fragmentary fracture between proximal and medium thirds of the tibiotarsus. The fracture was successfully repaired with an intramedullary pin and a reconstruction plate, which are less likely to result in muscular atrophy and do not require a second surgical intervention as the external fixators do. In conclusion, this case report shows that an association of a Steinman intramedullary pin and a reconstruction plate can be a less disturbing yet sill effective option to treat multi-fragmentary fractures in free-living birds, especially long-legged ones.
\end{abstract}

\section{Introduction}

The red-legged seriema (Cariama cristata) is the only bird from the order Cariamiforme that occurs in Brazil. They are long-legged, medium-sized birds that feed on small vertebrates and insects and that can be found mostly in open areas of central Brazil, also known as cerrado [1].

Currently, the most usual cause of death of red-legged seriemas in Brazil is by car accident, not only because of this bird's terrestrial habits but also because of the increasing process of urbanization in cerrado areas [2]. Car accidents, collisions, or other traumas involving high speed in general are more likely to result in multi-fragmentary fractures since birds have less soft adjacent tissues and thinner cortical bones when compared to mammals [3].

Multi-fragmentary fractures can be repaired by aligning the bone fragments and their two closest joints back to their anatomical position in a way so they can overcome muscular contraction strength, and there are many materials that can be used for that matter, such as external skeleton fixators, metal wires, intramedullary pins, and plates [4]. 
There are few studies regarding avian orthopedy, but even though plates are not commonly used in bird fracture repair, there are successful reports about their use. For example, Moraes and Hirano [5] concluded that internal implants are more likely to result in a satisfactory osteosynthesis than external fixing methods. Some authors state that external skeleton fixators may disturb the patient to the point that they excessively spare the fractured limb, resulting in a muscle atrophy due to member disuse [3]. Furthermore, since birds are bipedal animals, the recovery time of broken pelvic limbs must be brief, especially when dealing with wild birds [4].

Considering that the red-legged seriema is a terrestrial bird, the use of plate implants can be of advantage due the shorter recovery time when compared to external fixation techniques, granting more comfort to the patient and allowing a faster functional return of the damaged limb. Thus, this report describes a successful tibiotarsus fracture repair in a free-living red-legged seriema, using an intramedullary pin and a reconstruction plate.

\section{Case presentation}

An adult red-legged seriema (Cariama cristata) was found with an apparent background history of a runover. Mediolateral and ventrodorsal radiographic projections (Figures 1a,b) showed a multi-fragmentary fracture between the proximal and middle thirds of the right tibiotarsus's diaphysis.

The anesthetic protocol used in the patient was an association of $10 \%$ ketamine hydrochloride $(20 \mathrm{mg} / \mathrm{kg} / \mathrm{IM})$ and $0.5 \%$ midazolam hydrochloride ( $1 \mathrm{mg} / \mathrm{kg} / \mathrm{IM})$. After induction, the bird was placed in an anesthetic mask, subsequently intubated and manitained with isoflorane in oxygen.

Antisepsis was made in the damaged limb with alcoholic chlorhexidine from the distal portion of the right femur to the proximal portion of the metatarsus, cleaning the entire tibiotarsus length. The patient was placed in dorsal decubitus with the fractured member abducted, allowing craniomedial surgical access (Figure 2).

A skin incision was made, followed by a slightly divulsion of adjacent issues to properly access the fracture site. The tibiotarsus fracture after locating was reduced and properly immobilized with a Steinman intramedullary pin $(1.5 \mathrm{~mm})$, which was first inserted in a retrograde way and then in a normograde way so that the fragments were correctly aligned to keep the axial axis. A reconstruction plate $(2 \mathrm{~mm})$ was placed in the medial face of the tibiotarsus through a minimum-invasive technique. Four screws were inserted; two were proximal regarding the fracture site and two were distal (Figures 3a,b). The skin was later closed with simples and interrupted sutures of nylon 3-0 to cover the plate implant and allow healing by secondary intention. A non-steroidal anti-inflammatory (meloxicam) was administered intramuscularly $(5 \mathrm{mg} / \mathrm{kg}$ ) for five days.

\section{Discussion}

This report confirms that terrestrial birds are most likely to suffer traumas in their legs, as previously quoted by Canelas,

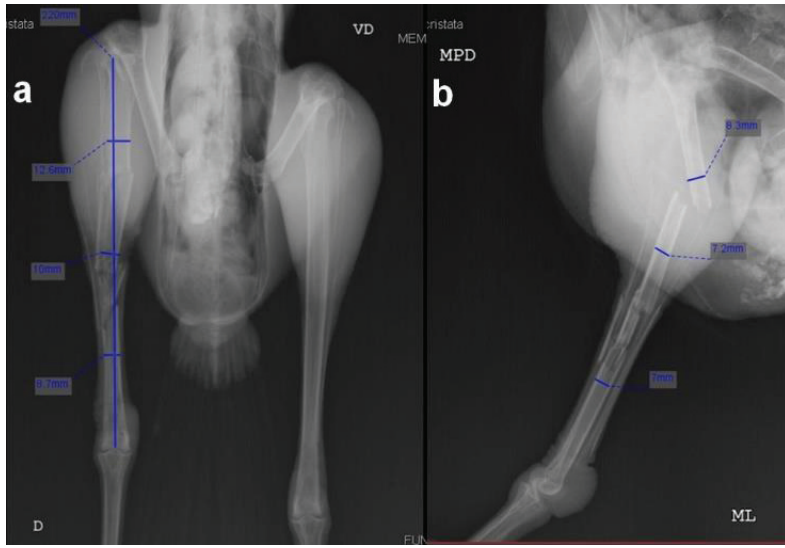

Figure 1a,b: Ventro-dorsal (a) and mediolateral (b) radiographic projections of the right pelvic limb in a red-legged seriema (C. cristata), revealing a multi-fragmentary fracture between proximal and middle thirds in the diaphysis of the tibiotarsus. Source: Author's personal archive.

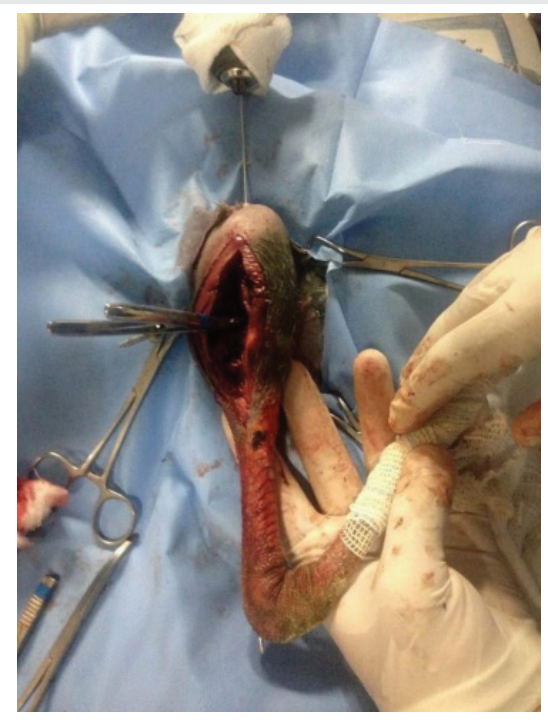

Figure 2: Abducted pelvic limb, allowing craniomedial surgical access to the fractured tibiotarsus.

Source: Author's personal archive.

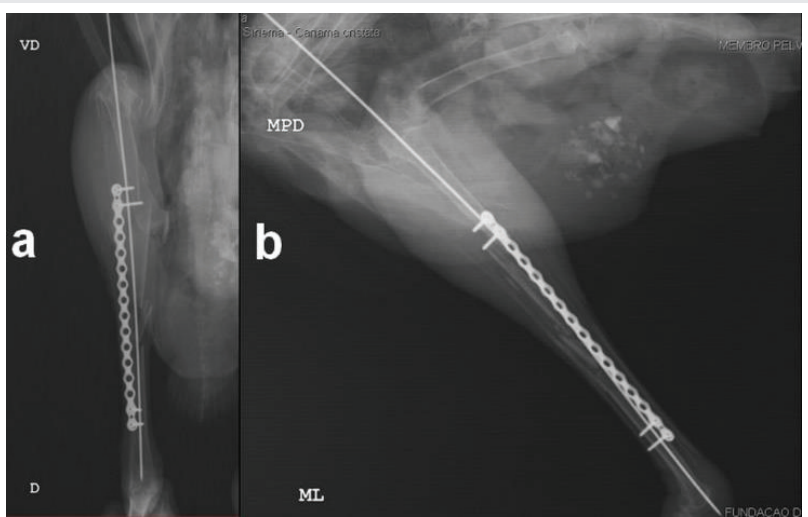

Figure 3a,b: Ventrodorsal (a) and mediolateral (b) radiographic projections immediately after the plate implant. It is possible to notice the Steinman pin and the reconstruction plate with the four screws correctly aligning all bone fragments and maintaining the proper axial axis.

Source: Author's personal archive.

et al. [6]. These authors also stated that most pelvic limb fractures usually occur in diaphysis due to the lack of muscular 
coverture, which also happened to the red-legged seriema (Cariama cristata) of this report.

Tibiotarsus fractures in birds normally require a medial surgical access to avoid major damage in nerves or blood vessels [6], as it was performed here.

Intramedullary pins are a not-so-expensive option with low tissular exposition that can provide precise axial alignment, resist against folding forces, and that can be easily introduced and removed [2]. They result in a good fixation, keeping the endosteal blood supply and therefore avoiding necrosis or iatrogenic fractures [6], which made us chose this fixation method for the patient.

Even though intramedullary pins are useful, they alone do not avoid rotation or compression forces over the fractured bone; their association to other repairing methods is therefore recommended [6]. Here, we opted for a plate because they result in a quick and stable bone union with a small fracture callous and, therefore, can provide an early functional return of the broken limb, improving the patient's comfort. Additionally, unless there is any apparent risk of complications, plates do not need to be retrieved from the patient after full fracture consolidation as they are usually biocompatible and capable of osteointegration, which is another advantage of the use of plates for fracture repair in free-living animals [7].

Comminuted fractures are not stable with just an intramedullary pin; rotational instability and axial compression may occur [8]. In complex fractures where many of the principles of plate application are compromised, the use of a plate associated with the intramedullary pin can prevent axial collapse and rotation. Reducing bone fractures using the best technique can cause complications such as bone nonunion, osteomyelitis and bone sequestration.

The main challenge of this case was the lack of repairing materials compatible with the patient's long legs. Even so, we chose a plate that covered at least $60 \%$ of the bone length to improve force distribution throughout the whole bone, as previously quoted by Canelas, et al. [6], and therefore, we noticed no limb deformation.

Thus, this report describes a successful association of an intramedullary pin and a reconstruction plate to repair a tibiotarsus fracture in a red-legged seriema. Considering our patient was a free-living bird and plates require less patient manipulation after surgery, the use of plates and intramedullary pins can be a viable option for consolidation of tibiotarsus fractures in wild animals, especially terrestrial long-legged birds such as the red-legged seriema (Cariama cristata).

\section{Acknowledgement}

This is a non-profit article without any sort of financial support. The authors have no conflicts of interest to declare.
We would like to thank the veterinarians Lanna Torrezan and Natália Todesco Torrejón who took care of the patient after the surgery.

\section{References}

1. Fontenelle JH, Barros LA (2014) Ciconiiformes, Pelecaniformes, Gruiformes e Cariamiformes (Maguari, Tuiuiú, Garça, Coelheiro, Jacamim, Saracura, Frango-d'água, Grou e Seriema). In: Cubas ZS, Silva JCR, Catão-Dias JL Tratado de animais selvagens: medicina veterinária. 2nd Ed. São Paulo: Rocca Press 1: 495-509.

2. Silva LM (2020) Levantamento de animais vertebrados atropelados em trechos das rodovias MG-352 e MG-190. Getec 8: 42-63.

3. Cueva LOB, Rahal S, Mesquita L, Mamprim MJ, da Trindade Alves AC, et al. (2020) Considerações sobre fraturas em aves. Vet E Zootec 27: 001-011. Link: https://bit.ly/3yg3piT

4. Carrasco CD (2019) Fracture management in avian species. Vet Clin North Am Exot Anim Pract 22: 223-238. Link: https://bit.ly/3hlueeF

5. Moraes IBS, Hirano LQL (2019) Redução de fratura tibiotársica bilateral em Asio clamator (Strigiformes: Strigidae): Relato de caso. 43f. Dissertação (Trabalho de conclusão de curso de graduação em Medicina Veterinária apresentado junto à Faculdade de Agronomia e Medicina Veterinária da Universidade de Brasília) - Universidade de Brasília. Link: https://bit.ly/3Aqpk91

6. Canelas HAM, Negrão AS, Hamoy AM, Cruz PSC, Neto RM, et al. (2020) Osteossíntese de ossos longos em aves: Revisão. Pubvet 14: 1-18. Link: https://bit.ly/3AjC062

7. Pires MAM, AmudeM AM, Machado CC, Freitas $\mathrm{SH}$, Minto BW, et al. (2020) Placa bloqueada em fratura tibiotársica de coruja suindara (Tyto furcata): relato de caso. Arq Bras Med Vet Zootec 72: 493-498. Link: https://bit.ly/2Uh3gNr

8. Johnson SA, Von Pfeil DJF, Dejardin LM, Weh M, Roe S (2012) Internal fracture fixation. In: Veterinary Surgery Small Animal. Tobias KM, Johnson SA Ed Elsevier Saunders 1: 576-607.

Discover a bigger Impact and Visibility of your article publication with Peertechz Publications

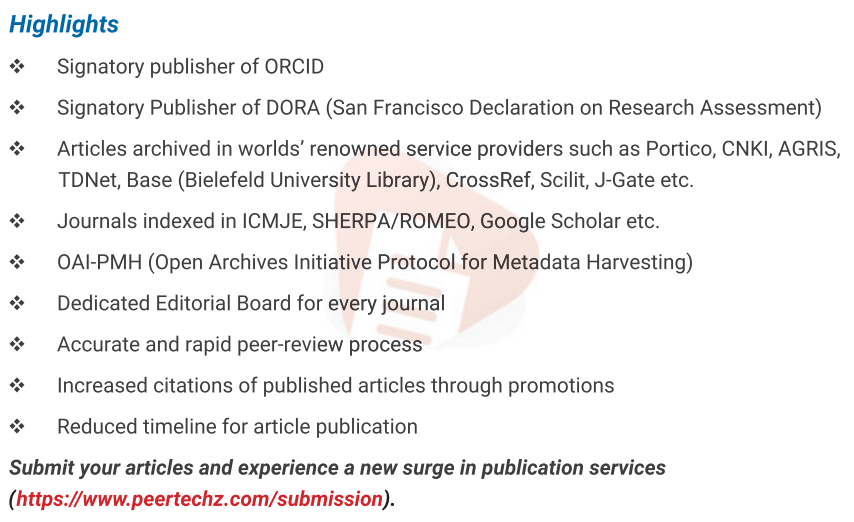

Peertechz journals wishes everlasting success in your every endeavours.

Copyright: @ 2021 Fernandes MC, et al. This is an open-access article distributed under the terms of the Creative Commons Attribution License, which permits unrestricted use, distribution, and reproduction in any medium, provided the original author and source are credited.

Citation: Fernandes MC, Mota da Costa AL, Da Silva Machado Camargo TF, Cotes LC, Friciello Teixeira RH, et al. (2021) Use of reconstruction plate and intramedullary pin for repair of a tibiotarsus fracture in a red-legged seriema (Cariama cristata, Linnaeus, 1766): Case report. Int J Vet Sci Res 7(2): 057-059. DOI: https://dx.doi.org/10.17352/ijvsr.000080 